\title{
Engaging College Students in Experiential Learning: Learning Through Serving, Inspiring Through Experience, and Creating Identity Through Bilingual Poetry
}

\author{
Shelli Rottschafer \\ Aquinas College, Grand Rapids, Michigan, USA
}

\begin{abstract}
Experiential learning is the opportunity to meld teaching with experience; "to do" the things students learn about in the classroom, yet outside the classroom walls. I am an instructor that embraces experiential learning. Every other year, I lead a Chican@ Literature class which, after the semester is finished, culminates with a two-week excursion to New Mexico. While on-campus I highlight specific themes within Chicano narrative and poetry. Discussions focus on several key aspects regarding Chican@ Literature whose purpose is to create a voice for those whom have been marginalized within mainstream American culture. Chican@ Literature emphasizes a concept of origin which is reiterated in New Mexico through a sense of place in nature. A second topic often addressed in Chican@ Literature is the idea of aprendizaje. This is a journey of knowledge. In each episode experienced, the narrative voice gains a broader understanding of identity. This aprendizaje is also shared by my students as they gain a sense of self as defined by their own community in juxtaposition with their New Mexican fieldwork and the bilingual poetry they write. Lastly, Chican@ Literature often reveals an author or poet’s personal culture clash or cultural fusion within the creative work itself. Once again, my students write about their own perspectives in a poetry workshop and presented their pieces during a poetry slam. Some of these pieces are included in this manuscript.
\end{abstract}

Keywords: service-learning, experiential learning, bilingual poetry, Chican@ Literature

\section{Introduction}

Experiential learning is the opportunity to meld teaching with experience; "to do" the things students learn about in the classroom, yet outside the classroom walls.

I am an instructor that embraces experiential learning. Every other year, I lead a Chican@ Literature class that once the semester is finished, culminates in a two-week excursion to New Mexico. While on-campus I highlight specific themes within Chicano narrative and poetry. Discussions focus on several key aspects regarding Chican@ Literature whose purpose is to create a voice for those whom have been marginalized within mainstream American culture.

Chican@ Literature and in this case Chicano bilingual poetry is an expression of creativity coming out of a community on the margin. The purpose of this body of literature is to create a voice for those whom have been marginalized. Issues typically addressed are a sense of place, or a concept of origin. Often this theme will reflect prejudices endured, discrimination suffered, and an "us verses them" division within the community.

Shelli Rottschafer, Associate Professor of Spanish, Doctorate of Philosophy in Spanish, Aquinas College. 
When considering our Chicano bilingual poetry readings by New Mexican authors, our understanding regarding a concept of origin gains a new perspective while in New Mexico. Our Service learning excursion reiterates a sense of place in nature in addition to raising awareness of agency, authority, adaptation, and assimilation.

A second topic of note often found in Chicano poetry is the idea of aprendizaje. This is a journey of knowledge. The narrator within the work gains a broader understanding of their own identity and a sense of self as defined by their community and society at large. Sometimes, the knowledge gained is acquired through a loss, a dislocation, and a subsequent finding or acceptance of self. This aprendizaje is also shared by my students as they gain a sense of self as defined by their own community in juxtaposition with their New Mexican fieldwork and the bilingual poetry they write.

Lastly, an emphasis regarding the poet's personal culture clash or cultural fusion guides the path they have chosen, or has been given to them. The culture clash can be a conflict between two languages, two belief systems, and two heritages. Or a cultural fusion can embody the intermixing, intermeshing, and coming together in that individual. Therefore the two, create one unique identity.

This final focus especially resonates with my students. To culminate our writing exercises in class, my students write about their own perspectives in a creative writing and poetry workshop. These poems were presented May 2014 while in Albuquerque, New Mexico to one of the Chicano poets we studied throughout our semester course. Mr. Levi Romero graciously gave us feedback and encouraged us all to continue our creative writing process. Romero's poetry collections are A Poetry of Remembrance: New and Rejected Works (2008) and his co-authored photo poetics text, Sagrado (2013).

\section{What Is the Purpose of Service Learning?}

“Across the United States and around the world, students and their instructors are leaving the classroom and engaging with their communities in order to make learning come alive and to experience real-life connections between their education and everyday issues” beyond the academic campus. (Cress, 2013, p. 9)

These types of connections I strive to facilitate in my Spring Semester Chican@ Literature course, which culminates in a two-week excursion throughout New Mexico. While on campus, class discussions and readings address immigration rights and adjustments to life within the "American Dream". Additionally, we reflect on our role influenced by our own culture(s) juxtaposed to life on the border and Spanish speaking Latino communities in the United States.

Not only do we read Chicano narrative and poetry supplemented with socio-historical texts, there is also a service-learning component to the course in which we volunteer in Gallup, New Mexico on the Navajo Reservation within the Head Start afterschool program at Rehoboth School as well as in Española, New Mexico at the Española Valley Animal Shelter. These experiences demonstrate, like Christine Cress emphasizes in Learning Through Serving that, "Service-Learning invites you to bring who you are, what you know, and what you can do into the classroom and the world beyond... [in order to create] community change” (Cress, 2013, p. 37).

Courses such as my Chican@ Literature class make both the instructor and the student, question their own personal identity and help solidify this developing identity. That is to say, "Putting who you are and what you know into practice will change who you are and... enlarge your understanding of yourself and the world of others who are both different from and similar to you” (Cress, 2013, p. 37). 
"In forming a community with others...you increase the possibilities for creating transformation" (Cress, 2013, p. 37). However, Rachel Naomi Remen (1999) quoted in Cress, reminds participants in service-learning projects to be aware of the differences and intentions behind the acts of helping, fixing, and serving. Remen explains that, "Helping is not a relationship between equals. A helper may see others as weaker than they are, needier than they are, and people often feel this inequality" (Cress, 2013, p. 45). "In fixing, we see others as broken... Fixers trust their own expertise but may not see the wholeness in another person or trust the integrity of the life in them" (Cress, 2013, p. 45). Yet, "When we serve, we see and trust that wholeness. We respond to it and collaborate with it. And when we see the wholeness in another, we strengthen it" (Cress, 2013, p. 45). "The 'learning' part of the term service-learning suggests that we have powerful opportunities to learn and to grow... [True] reciprocity can result from our interactions” (Cress, 2013, p. 46).

Chican@ Literature taught through a Service Learning lens helps engage students in the formation of their own identity. The Service Learning component teaches collaboration within a community of equals. The purpose of reading bilingual poetry and then creating our own helps the student-author voice their concept of origin, their journey of aprendizaje, and a new understanding of reciprocity based on their own cultural clashes or fusions.

\section{Why Bilingual Poetry Works in Service-Learning Courses}

Sonia Nieto, a well published author on the effects of language and culture in teaching within the United States, advocates for creating a classroom of acceptance where students' identity is affirmed through multiculturalism and multilingualism.

Nieto explains that sociocultural perspectives regarding teaching are based upon,

the assumption that social relationships and political realities are at the heart of teaching and learning. That is, learning emerges from the social, cultural, and political spaces in which it takes place, and through the interactions and relationships that occur between learners and teachers. (2010, p. 4)

This is supported by Paulo Freire's educational pedagogy theory (1985) which states, "To study is not to consume ideas, but to create and re-create them" thereby establishing a mutual discovery shared by students and their teachers (Nieto, 2010, p. 5).

The above idea I promoted in our Chican@ Literature class’s final poetry project on campus, which then facilitated our Poetry Slam May 2014 in Albuquerque, New Mexico with Chicano Poet, Mr. Levi Romero. This experience enabled my students to reflect upon their own experiences through bilingual poetry and transmit knowledge about their own culture(s). This was not only a learning process for the student-authors to eloquently express themselves in writing but also created an opportunity for the audience to learn from the student-authors' multicultural perspective.

I believe this project was such a success because our community in Grand Rapids, Michigan and on campus at Aquinas College is seemingly very homogeneous. However, as the student-authors shared their bilingual poetry, their cultural differences gained a voice within a safe space, whether in our classroom or performed at the Poetry Slam.

As one reads the following student-authored poetry, each piece includes a concept of one's past, a road taken along which knowledge has been gained, and where cultural fusion or clashes have occurred. These student-poets challenge their readers to accept their own sense of place, continue their path toward understanding, and to acknowledge the struggles they have encountered in order to evolve. 


\section{Higgins Lake}

Sydne Harris

Vengo del lago Higgins

180 feet of ground cold spring-fed water

$Y$ es el líquido que está en mis venas

Sleepy cabins and misty mornings

Dirt roads and wooden docks

Higgins Lake

¿Ha visitado?

Es un secreto that too many do not keep

We flinch at their un-earned claims:

"Tengo una casita allí"

"I’ve vacationed there since I was little"

¡Por favor!

Clean up your mess

Pack your coolers

Soy la hija de nativos orgullosos

Brutal Northern Winters

Solo tres meses de glorious sun

Es el precio que pagamos para ser locales

This is how they raised us

Soy de las travesías a las dos de la madrugada

Bare feet flying

Down the dirt roads

Through the sand

On the dock

The boats nestled safely in their hoists

Under their canopies

\section{Nosotros}

Protegidos debajo de una manta de las estrellas

Navigational lights

Rojo y Verde 
Somos amigos with the downstaters

And the Bud-Light they steal from their parents’ coolers

Soy de quart jars of stewed tomatoes

Chili sauce and beets

Wild blueberries and spearmint

Sun tea

Humming birdfood

Hot

Sticky

Red

Soy de los deberes a las cinco de la mañana

Cuando a los trece años

I'd ride my bike down the lake road

In the light of dawn that looked like dusk

Aprons

Hot aceite

Fry-cakes

A long john for the early-morning fisherman

"Creme-filled, please"

Vengo del lago Higgins

Una escuela

Una iglesia

45 minutes to the nearest supermarket

Nada más

Soy de choppy whitecaps y

Warm western breezes

That carry the smell of shore line bonfires

Across the rippling nightwater

Its in the tint of my skin

Es el latido de mi corazón 


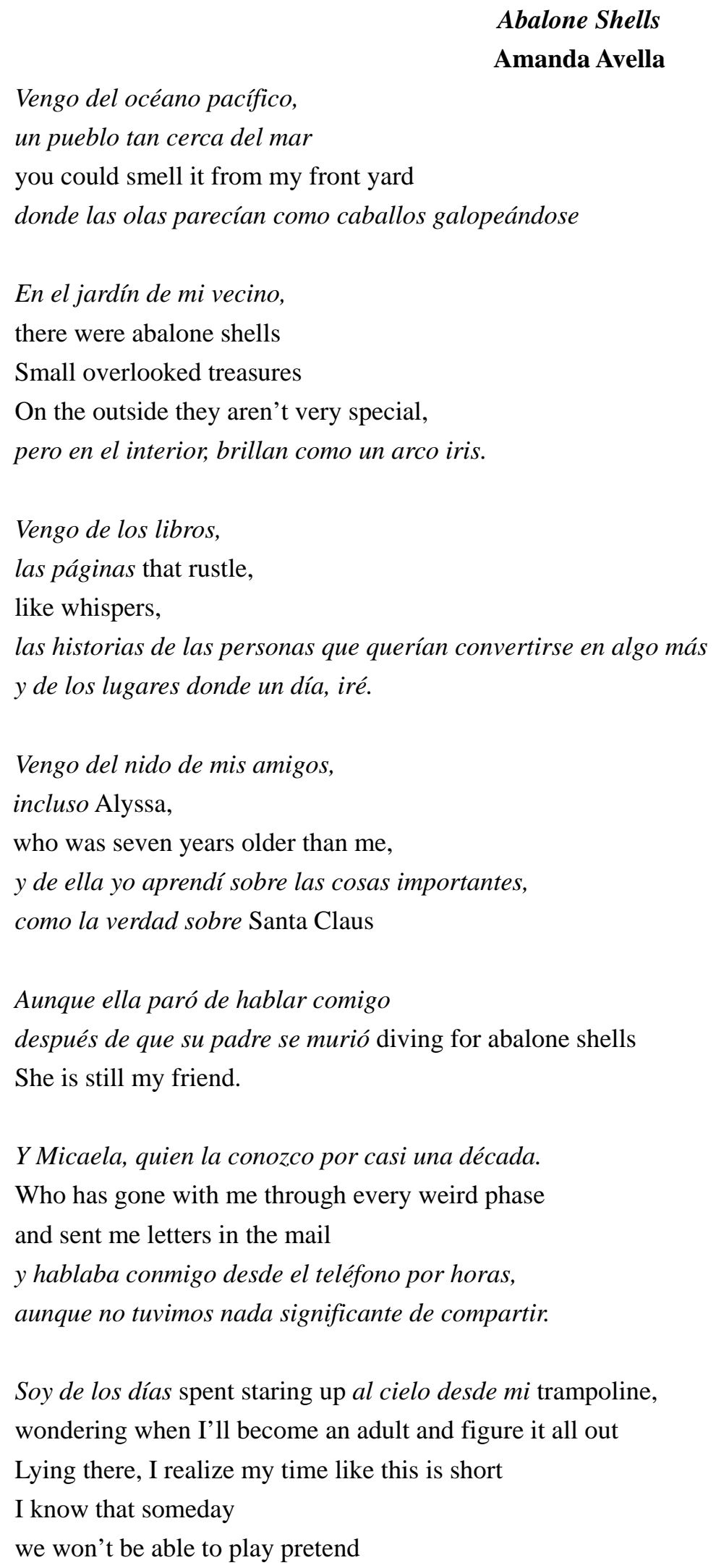

Soy de los días spent staring up al cielo desde mi trampoline, wondering when I'll become an adult and figure it all out Lying there, I realize my time like this is short

I know that someday

we won't be able to play pretend 
Alyssa taught me that

but I don't need to know those secrets today

So, I jump off and dig my bare feet into the ground.

Yo soy la hija de mi madre,

quien me apoya sin condiciones,

as long as I never ride a motorcycle

or get a tattoo

Durante mi primer día a la universidad,

mi madre me preguntaba porque estaba llorando,

solo pude decir, "I miss my cat”.

Ahora vivo en Michigan

Un pueblo, that doesn't smell del mar

y mis vecinos no tienen

abalone shells en sus jardines

pero está bien.

Un día me gustaría caminar la calle donde yo crecía

to see if there are still abalone shells

en el jardín

And if there are

tocará la puerta

wondering if Alyssa todavía piensa en mí. 


\section{Soy de aquí, y soy de allá \\ Peri Erhan}

Soy de aquí,

playing in the fields behind my grandmother's house

where I learned to catch grasshoppers and climb trees

Y soy de allá,

spending my summers at the ada on the Maramara Sea

chasing around stray dogs and

watching the lights from Istanbul from my bedroom window

Soy de aquí,

where my curfew was being home "by streetlights"

and a place where we never locked our doors

Y soy de allá,

where the man is the head of the household

and the woman is not heard

Soy de aquí,

where we go camping in the summer

sledding in the winter

drink fresh apple cider in the fall

and ride our bikes in the spring

Y soy de allá,

where we eat lamb instead of beef

and drink raki instead of beer

Soy de unafamilia of 2 brothers, 4 sisters, and 32 cousins

una familia of "every other weekends"

one weekend at St. Alphonsus learning the Bible

and one weekend at the Mosque learning the Quran

Soy de aquí, where you are hated for being a Muslim

$Y$ soy de allá, where you are hated for being a Christian

Soy de aquí, with the water from Lake Michigan flowing through my veins

$Y$ soy de allá, with the wind from Bürgazada blowing in my hair

Soy de aquí, y soy de allá,

I am from here, but I am also from there. 


\section{References}

Cress, C. M., Ollier, P. J., \& Reitenauer, V. L. (2013). Learning through serving: A student guidebook for service-learning and civic engagement across academic disciplines and cultural communities. (2nd ed.). Sterling, VA: Stylus.

Freire, P. (1985). The politics of education: Culture, power, and liberation. NY: Bergin \& Garvey.

García Bedolla, L. (2009). Latino politics. Cambridge: Polity Press.

Gómez, L. E. (2007). Manifest destinies: The making of the Mexican American race. NY: NYU.

Herrera, S., Kaiser, R., \& Romero, L. (2013). Sagrado: A photo poetics across the Chicano homeland. Albuquerque: UNMP. Nieto, S. (2010). Language, culture, and teaching: Critical perspectives. (2nd ed.). NY: Routledge.

Remen, R. N. (September 1999). Helping, fixing or serving? Retrieved from http://www.shambhalasun.com/index.php?option=com_conten\&task=view\&id=2328

Romero, L. (2008). A poetry of remembrance: New and rejected works. Albuquerque: UNMP.

Vázquez, F. H. (2009). Latino/a thought: Culture, politics, and society. Lanham: Rowman \& Littlefield Press. 


\section{Appendix A: Biographies}

\section{Sydne Harris}

Ms. Harris is a 2014 Aquinas College graduate in Community Leadership and Spanish. Her passion is advocating for marginalized people and giving voice to women's issues such as the need for education and stopping domestic violence.

Sydne is from the small town of Higgins Lake, Michigan a picturesque inland lake town with a State Park. She holds nostalgic memories of her childhood and emphasizes her connection with a sense of place, that of Higgins Lake. She has felt the positives and negatives regarding her concept of origin. She has a strong idea of who she is in juxtaposition with those who claim authority within her hometown. In her poem she addresses an "us verses them" division within the community. Yet, overall she embraces the notion of accepting others as part of the evolutionary process of accepting one's self.

\section{Amanda Avella}

Ms. Avella, class of 2016, is a Biology and Spanish double major. Her joy is found in nature and self expression as she also tutors in the Aquinas Student Academic Services Writing Center.

Amanda is an excellent peer mentor. She understands that life, and the experiences one encounters, is the ultimate teacher. Her poem, “Abalone Shells” is an episodic journey through her childhood. She details her pivotal points in life, moving away from the West Coast to Michigan, loss of kindred spirits, and her own coming of age. Ultimately, her dislocation has led to her own acceptance of self.

\section{Peri Erhan}

Ms. Erhan graduated May 2014 as a dual major in Spanish and Psychology. Peri is new to writing poetry but feels proud to share her story regarding her cultural background and cultural differences.

“I am from here, I am from there” highlights Peri’s Turkish and Polish-American heritage. Her poem emphasizes both the culture clash and cultural fusion that created who she is as a young outspoken woman living within two cultures.

\section{Dr. Shelli Rottschafer}

Dr. Shelli Rottschafer attended Hope College in Holland, Michigan for her BA in Spanish and History (1996). She completed her Masters in Spanish from Miami University in Oxford, Ohio (1999). In 2005 she completed her doctorate from the University of New Mexico in Latin American Contemporary Literature. Additionally, she earned her Teaching Certificate from The Santa Fe University of Art and Design in New Mexico (2005).

Since Fall 2006, Dr. Rottschafer has taught at Aquinas College, a small liberal arts college in Grand Rapids, Michigan. She teaches Spanish Language and Writing courses, Chican@ / Latin@ Literature, and Hispanic Film. She also leads experiential and service learning projects. Fall 2014, Dr. Rottschafer was appointed the Director of the Contemporary Writers Series, which invites four acclaimed authors to campus throughout the academic school year. Previous authors of note have been Luis J. Rodríguez, Luis Alberto Urrea, Peter Ho Davies, and Sarah Kay. In addition to this role, Dr. Rottschafer also has begun teaching First-Year Composition within the Department of Inquiry and Expression. 